\title{
Socioeconomic Implications of Water Pollution in an Urban Environment A Case Study in Meda Ela Catchment, Kandy, Sri Lanka
}

\author{
Postgraduate Institute of Agriculture \\ University of Peradeniya \\ Sri Lanka
}

A.W.G.N. Abeygunawardane, N.D.K. Dayawansa ${ }^{1 *}$ and S. Pathmarajha ${ }^{1}$

\begin{abstract}
Meda Ela is a tributary of Mahaweli river. It has a complex catchment area with diverse type of land uses including densely populated urban areas. With urbanization and population pressure, Meda Ela is increasingly getting polluted due to direct disposal of solid waste, grey and black water. Polluted water from this tributary ultimately drains into the Mahaweli River which is the main source of drinking water for Kandy city and the suburbs. The objective of this study was to assess the socio-economic implications of water pollution in Meda Ela. A structured questionnaire survey was conducted with a randomly selected sample of 100 households within the 18 Grama Niladari Divisions (GNDs) of the catchment area to collect primary data. In addition, people from small businesses, commercial and public establishments such as small restaurants, central market, hospitals, etc. were interviewed to collect necessary data to identify impacts of water pollution on them and their opinion on pollution of Meda Ela water. Focused group discussions, and a number of key informant interviews were also held to gather relevant information. The results show that the level of water pollution is high in Meda Ela due to unplanned and inadequate waste disposal facilities and indifferent attitude of the people. The study revealed that occurrence of diseases, provision of breeding grounds for mosquitoes, and emission of unpleasant odour are the major impacts of water pollution. In addition, people who live closer to the canal suffer from flash floods during rainy seasons and bad odour during dry spells. Despite 93\% of the community having a good educational background, they continue to dispose and discharge solid and liquid wastes into the stream. Though there are a large number of government sector stakeholders directly or indirectly involved in water resources management of the area, the degree of interactions and collaborations among them vary widely. This study recommends that there should be a community based management system to minimize the pollution of water in Meda-Ela and thereby to minimize the socio economic impacts of water pollution in the catchment.
\end{abstract}

Key words: Meda Ela, Mahaweli River, Water Pollution, Social Impacts

\section{INTRODUCTION}

Urbanization is believed to be an important cause of destruction and degradation of natural water resources. With rural-urban migration, it has been estimated that by the year 2025 , approximately fifty percent of the population will live in growing cities of less developed countries (Jayakody et al., 2006). Urban water pollution has emerged as one of the most

To whom correspondence should be addressed: dammid@pdn.ac.lk

Department of Agricultural Engineering, Faculty of Agriculture, University of Peradeniya, Sri Lanka. 
critical forms of environmental degradation in Asia. In Asian countries, water pollution is clearly an environmental and political issue (Storey, 2005). Water pollution, which is a common phenomenon in almost all Asian urban areas, results from the environmental impacts of urban growth, failure of regulations, and the increase of unplanned settlements with lack of basic sanitary and sewage systems. On the other hand, this is partly a result of the failure of the state institutions, weakness of central and local authorities and the historical negligence of environmental issues (Storey, 2005).

Mahaweli is the largest river basin in Sri Lanka, draining about $16 \%\left(10,327 \mathrm{~km}^{2}\right)$ of Sri Lanka's land surface. In recent times, with increasing population and rapid urbanization, settling around townships, especially on the banks of Mahaweli, has shown a marked increase causing significant pollution of this important water resource. Kandy, the second largest city in Sri Lanka, is believed to contribute a significant amount of pollutants into the headwaters through a number of tributaries including Meda Ela, Pinga Oya, Maha Oya, etc. around the city (Wijekoon and Herath, 2006). Many socio-economic and environmental problems have been created as a result of releasing untreated sewerage and domestic wastewater directly into the Mahaweli river.

The census of population and housing in 2001 revealed that the total population of Kandy district was $1,279,028$. Kandy city also caters to a floating population of 157,000 during day and 111,000 during night (Abeysinghe, 2007). The total daily drinking water consumption is about $25,000 \mathrm{~m}^{3}$. Assuming the conversion rate of $80 \%$ with respect to the total amount of water used, the wastewater release is $20,000 \mathrm{~m}^{3}$ per day. Since there is no proper wastewater disposal system, they are released to the surface water bodies or streams (Abeysinghe, 2007).

\section{The study area}

Meda Ela catchment (Fig.1) is an urbanized sub-catchment that covers substantial part of Kandy city, mainly consisting of commercial establishments, residential areas and hospitals. Some of these buildings have direct sewerage outlets connected to the stream. It also receives waste directly and indirectly from tourist hotels, schools, Kandy central market, slaughter house and laundries. A network of wastewater canals draining from various parts of Kandy city are connected with Meda Ela while it flows towards Mahaweli. In addition, it is fed by a number of perennial and seasonal streams draining from the adjacent hilly terrain.

The uppermost branch streams of the canal are being used by people for bathing, washing and even for drinking without purifying the water. Though the latter part of the canal is polluted, economical benefits are received by the people who are engaged in laundry business and the people who collect worms as fish feed. However, the majority pay additional cost for water purification due to results of direct dumping of waste into the canal. 


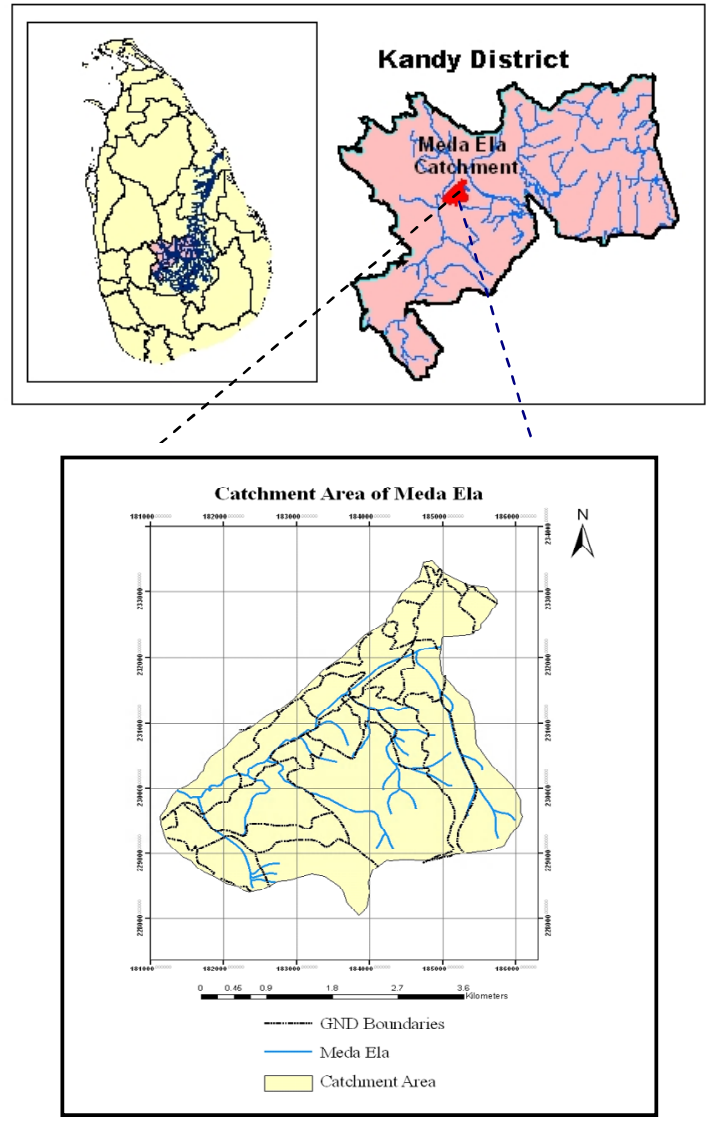

Fig. 1. Location map of the study area

\section{Rationale}

Meda Ela has hardly been subjected to a systematic assessment of socio-economic impacts due to water pollution though it is a potential threat to the people living in the vicinity. There had been a few sociological studies carried out for different purposes and no reference has been made to water pollution levels of entire catchment of Meda Ela. Thus, this study is devoted to assess the socio-economic implication of water pollution in Meda Ela catchment. Further, it analyses the stakeholders in the catchmet and their role in managing the catchment.

\section{METHODOLOGY}

The Kandy city and the surrounding area comprises of 30 Grama Niladhari Divisions (GNDs). Of these 30 GNDs, 18 GNDs which fall into Meda Ela catchment were selected for this study. A questionnaire survey was conducted with a sample of 100 households to collect primary data. The number of respondents was selected from each GND proportionate to the population in the respective GNDs. In addition, 15 businesses, commercial and public establishments were surveyed to collect necessary data for the identification of major sources 
and types of pollutants. Three focused group discussions and key informant interviews were conducted to collect socio economic information and to triangulate the collected data. The data were analyzed using MS Excel and SPSS statistical programmes. Correlation and Chisquare testes were applied as required. In addition, institutions and other stakeholders which are operating in the study area were consulted to identify and assess their roles in controlling water pollution.

\section{RESULTS AND DISCUSSION}

\section{Descriptive statistics of household survey}

Table 1 presents the basic statistics gathered from the study area. Of the 100 respondents, 52 were females. Only $19 \%$ of the respondents were engaged in government employment while $37 \%$ were employed in the privet sector. Farming was not a popular activity in the area. Paddy lands in the catchment were spread as small patches of 0.2 to 0.4 ha and these lands are not cultivated regularly. Therefore, the disposal of agricultural wastes into the canal is assumed to be at a negligible level.

The average age of the respondents was 41 years. The average land extent owned by a household was 12.84 perches $\left(25.29 \mathrm{~m}^{2}\right)$. Average family size was five and average daily consumption of water per family was $995 \mathrm{~L}$. The average amount of waste water generated by a family was approximately $796 \mathrm{~L}$ which accounts for nearly $80 \%$ of the total water consumed by a household. Average household solid waste generation was $1.5 \mathrm{~kg} / \mathrm{day}$.

Table 1. Descriptive statistics of the respondents

\begin{tabular}{lllll}
\hline Variable & Minimum & Maximum & Mean & $\begin{array}{l}\text { Std. } \\
\text { deviation }\end{array}$ \\
\hline Household characteristics of the catchment & & & & \\
Age (yrs) & 20 & 72 & 41.3 & 12.0 \\
Land extent/family (Perches) & 0.9 & 120 & 12.8 & 14.5 \\
$\begin{array}{l}\text { No. of family members } \\
\text { Water usage/family/day (L/day) }\end{array}$ & 2 & 10 & 5.0 & 1.7 \\
$\begin{array}{l}\text { Waste generation } \\
\text { Wastewater generation/family (L/day) }\end{array}$ & 125 & 5033 & 995. & 714.8 \\
$\begin{array}{l}\text { Solid waste generation/family (kg/day) } \\
\text { Cost due to water pollution of Meda Ela (Rs.) }\end{array}$ & 0 & & & \\
Health cost (1 incident/person) & 0 & 5026 & 795.9 & 571.9 \\
$\begin{array}{l}\text { Cost for odour control (Monthly) } \\
\text { Cost for mosquito control (Monthly) }\end{array}$ & 0 & 7000 & 4.6 & 0.9 \\
Cost for flood control (Annual) & 0 & 0 & 0.0 & 0.0 \\
\hline
\end{tabular}

There are different ethnic groups living in the area. Majority (66\%) of the sample constituted of Sinhalese, 23\% Muslims and 10\% Tamils. Considerable variation of waste generation was seen among the ethnic groups. The survey revealed that the daily solid waste generation by an average Sinhala family is usually less than $2 \mathrm{~kg}$ while Muslim families generate more waste when compare to the other ethnic groups (Table 2). However, there were two non-Muslim families in extreme conditions (waste generation was more than 5 $\mathrm{kg}$ /day). Waste generation pattern could be related to the income levels and consumption patterns of the people. 
Table 2. Linear correlation between ethnicity and solid wastes

\begin{tabular}{lrrrl}
\hline Ethnicity & Solid & \multicolumn{2}{c}{ waste/family/day $\mathbf{( k g )}$} & Total \\
\hline & $\mathbf{0 - 2}$ & $>\mathbf{2 - 5}$ & $>\mathbf{5}$ & \\
Sinhala & 53 & 11 & 2 & 66 \\
Tamil & 8 & 2 & 0 & 10 \\
Muslim & 4 & 19 & 0 & 23 \\
Other & 1 & 0 & 0 & 1 \\
Total & 66 & 32 & 2 & 100 \\
\hline
\end{tabular}

The education level is fairly good and $94 \%$ of the respondents in the sample had sat for the G.C.E. (O/L) examination. Results of the Spearman's correlation analysis showed that there is a significant correlation at 0.01 level (2-tailed) between education and legal awareness of waste disposal into water bodies. It implies that the higher the level of education, higher the level of awareness on legal aspects of waste disposal into water bodies.

\section{Wastewater discharge and solid waste disposal}

Most of the inhabitants were aware of the legal conditions related to disposal of waste and waste water into water bodies. People discharge wastewater directly into the canal in the absence of an alternate way to discharge waste water. The concerned dwellers who had enough space have dug pits to collect waste water while all the others drain waste water into the nearest water way or indirectly to a trench which is ultimately connected to Meda Ela. However, $30 \%$ of the sampled households directly discharge wastewater into the canal. Their opinion is that gray water discharge to the stream is not harmful compared to the release of black water.

Water Supply Augmentation Project (2002) has estimated that the sewerage or black water inflow to Meda Ela is at $1,500 \mathrm{~m}^{3} /$ day. The survey results have further elaborated this finding through the available methods of sewage disposal as illustrated in Fig. 2. Pit type toilets are the most common and septic tanks are the next common category. However, $5 \%$ of households direct their sewage to the canal itself as an easy method of disposal neglecting the adverse side effects.

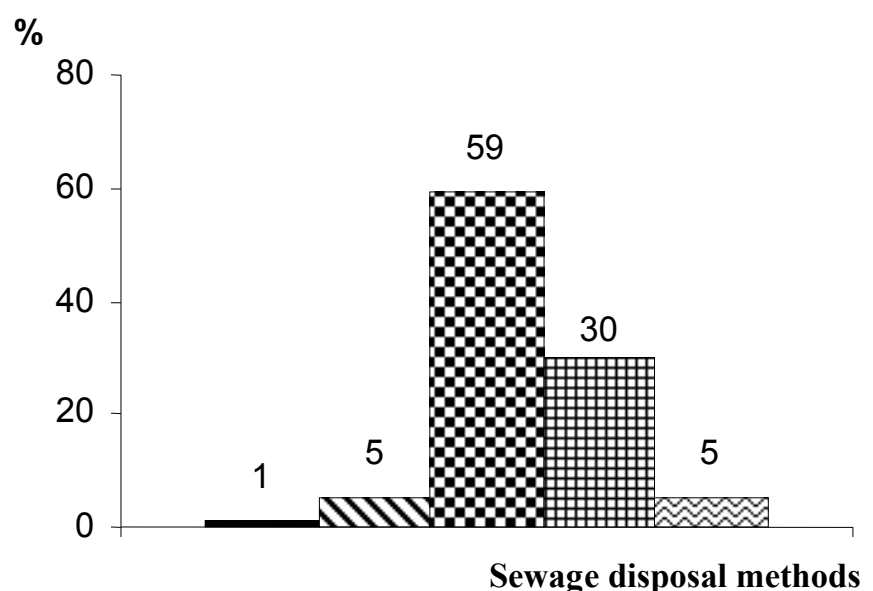

No latrine
Pit latrine
Septic tank
Direct to the
canal

Fig. 2. Sewage disposal methods used by the households 
According to the focused group discussions, it was revealed that most of the people who live along the canal bank, flush out their sewerage pits during heavy rains to avoid paying for gully suckers to empty them. This is an ideal example to show the way of contaminating Meda Ela water as a result of a congested urban environment and lack of community awareness on possible environmental consequences of contaminating water resources with sewerage.

According to the Situation Report of UDA (2001) and Situation Report of UD (2005) nearly 100 tonnes of municipal solid waste is generate per day within the Kandy city. According to the survey results, $9 \%$ of the households use canal as a direct dumping site for their solid waste. It was revealed that, even the people who reside outside the catchment also dispose solid waste into the stream, especially during night times. The residents who live near the canal oppose dumping of solid waste into the canal since these wastes block the water course and create problems to them.

\section{Impacts of water pollution}

According to the perspectives of the respondents, $36 \%$ consider water pollution of Meda Ela creates detrimental effects to their health and sanitation (Table 3). According to the disease incidents of recent past, $13 \%$ of the families have got affected by dengue and chickengunya fever. The total affected individuals were 18 and the mean health cost was Rs.453.00 per incident.

People are aware that the canal provides an ideal breeding ground for mosquitoes due to stagnating water during dry weather conditions as a result of low water flow. This condition is further aggravated due to solid waste disposal and wastewater discharge. People in the area have got used to mosquito nets, repellent coils, repellent mats and fans to protect from mosquito bites. Monthly average cost for mosquito repellents was Rs.162.00 per family.

Nearly $54 \%$ of the people, almost all the households near the bank of the canal, reported that they suffer from to bad odour (Table 4) and another 28\% said that they feel a strong odour during dry season. The rest reported that they do suffer due to bad odour from time to time in both dry and wet seasons. The major problem associated with the odour is its inevitability throughout the year though it appears in different magnitudes.

Since the canal is the drainage path of the whole Kandy city area, flash floods after heavy rains are very common. It was revealed that $30 \%$ of the sampled households that live closer to the canal are affected by intermittent floods. The canal is not in a position to absorb heavy loads of solid waste since it is already in a saturated condition. There is a considerable input of eroded soil too into the canal. Blocking and narrowing of drainage paths by waste material and sediments pave the way for flash floods during heavy rains.

Table 4. Major impacts of water pollution in Meda Ela

\begin{tabular}{lc}
\hline Major Impact & Positive respondents (\%) \\
\hline Health impacts & 36 \\
Odour problem & 54 \\
Mosquito problem & 82 \\
Flooding & 30 \\
\hline
\end{tabular}




\section{Major water related stakeholders and their relationship with each other}

Kandy Municipal Council (KMC), Central Provincial Council (CPC), Kandy Divisional Secretariat (KDS), Gangawata Korale Pradeshiya Sabha, Urban development Authority (UDA), Central Environmental Authority (CEA), National Water Supply and Drainage Board (NWS\&DB), Irrigation Department (ID), commercial establishments, individuals and residents are the key stakeholders who live in the catchment of this canal. KMC is responsible for cleaning and maintaining the canal as the stream flows through an area which comes under their jurisdiction. In addition, Gangawata Korale Pradeshaya Sabha, Central Provincial Council, District and Divisional Secretariats of Kandy are collaborating with the $\mathrm{KMC}$ in granting permission for constructing buildings, houses, etc. and providing approvals for management and development activities related to the water bodies. Other government related institutions such as ID, CEA and UDA are also involved in water related development activities in the area. Most of the residential population and the business community neglect their social responsibility towards proper waste disposal and wastewater management. Hence, these categories can be identified as key polluters. Usually, the Public Health Inspector (PHI) with the help of the community health officers organizes different awareness programmes and campaigns on reducing epidemic diseases in the community. According to the performances among all above stakeholders, a degree of relationship exists as shown in Fig. 3.

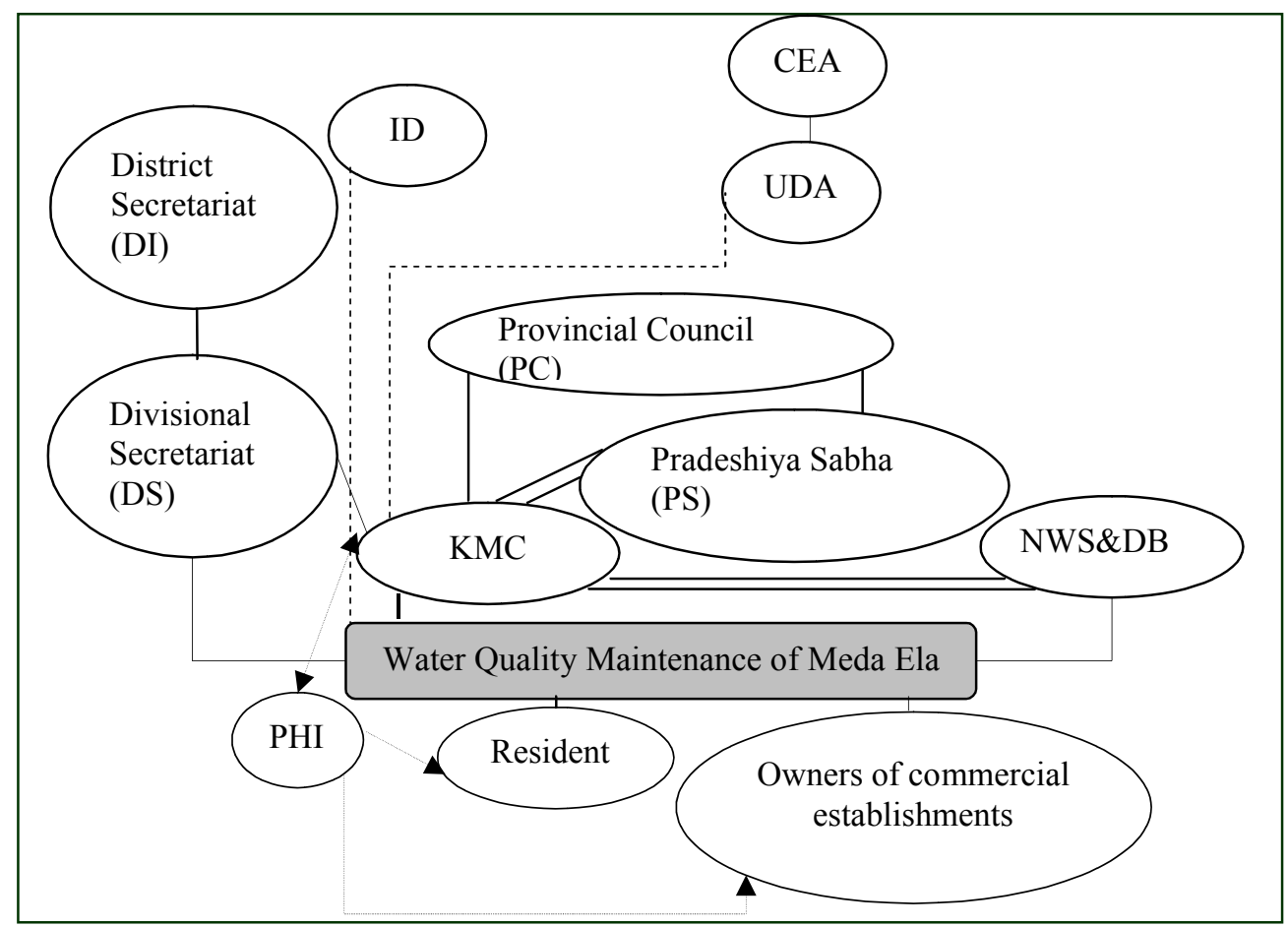

Circles indicate the stakeholders

A square or rectangle indicates an issue

Straight lines indicate links and close relationships

A double connecting line indicates an alliance

Dotted lines indicate informal or intermittent links

Arrow indicate the pre dominant direction of influence or activity

Fig. 3. Relationship among stakeholders 
Abeygunawardane et al.

\section{Contribution from different sectors in the society to water pollution in Meda Ela}

The ranked order of the responsibility in controlling water pollution as perceived by the respondents is presented in Table 5. The Kandy Municipal Council (KMC) got the highest score as it is the authorized government agency for cleaning and maintaining Meda Ela and its catchment area.

Table 5. Responsibility in controlling water pollution as ranked by the respondents. (Results of the Matrix Ranking exercise)

\begin{tabular}{lcc}
\hline Responsible institutions/ individuals or groups & Score & Rank \\
\hline 1. KMC & 399 & 1 \\
2. People live along the canal & 340 & 2 \\
3. Kandy Central Market and hospitals & 214 & 3 \\
4. Other (Slaughterhouse, Hotels, etc.) & 37 & 4 \\
5. Visitors to Kandy city & 34 & 5 \\
\hline
\end{tabular}

The residents live along the canal bank have a greater responsibility towards controlling water pollution. Though there are different social organizations in every Grama Niladhari Division, no collective actions have been taken to reduce the pollutant loading to Meda Ela. The canal reservation is encroached by people maybe as a result of high land value in the area, political blessings and poor response of the law enforcing authorities to control these activities. In addition, the field observations confirmed that hospital and central market (Fig. 4) wastes also significantly contribute to the pollution status of Meda Ela.

The slaughterhouse at Suduhumpola which is managed by KMC does not have a proper waste water disposal mechanism as shown in Fig. 5. This slaughterhouse generates an estimated 10,509 L of waste water per day in addition to blood and urine (estimated as 160 $\mathrm{L} /$ day). It was identified that the people who live in the surrounding have already reported to the relevant authorities regarding the improper disposal of waste water from this place.

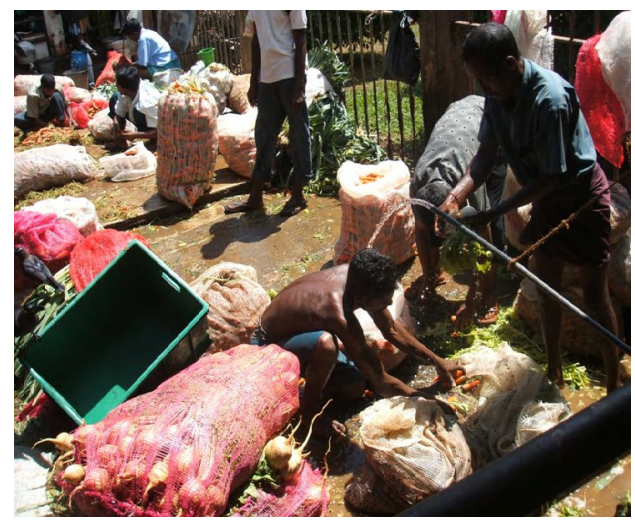

Fig. 4. Washing out the debris of vegetables at Kandy central market

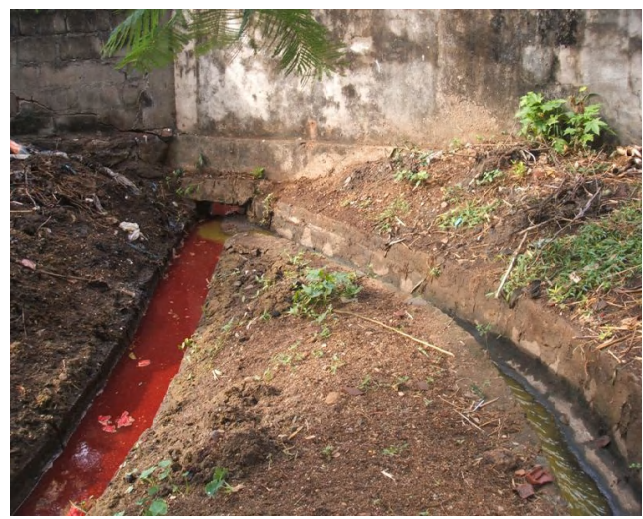

Fig. 5. Wastewater out let slaughter house

Absence of or poor capacities of waste treatment plants in small scale hotels and restaurants also contribute to high waste loading to water courses. Waste water from these establishments can also ultimately end up in Meda Ela. Being the main urban centre of the 
central province and due to its cultural and environmental importance, Kandy attracts a considerable number of visitors including locals and foreigners. Hence, the city has to handle the waste material generated by this floating population too which can significantly contribute to pollution of Meda Ela water.

\section{CONCLUSIONS}

Meda Ela has a complex catchment area which consists of urban centers, densely populated residential areas, hospitals, market places and a number of government and private sector institutions. As a result, Meda Ela water is polluted due to solid and liquid waste generated from multiple sources. Vector borne diseases such as Dengu and Chickengunya, mosquito breeding, bad odour and flash floods are the direct consequences of water pollution and blocking of canal due to solid waste and sediments.

The awareness on water pollution due to waste disposal is high among the communities that live within the catchment as their educational level is good. However, discharge of gray water as well as black water by people who live close to the canal is evident. Though their awareness on water pollution and possible consequences is high, they still continue to practise these activities due to lack of options for proper disposal of solid and liquid wastes. Since Meda Ela is the drainage path for the entire Kandy city area, flash floods after heavy rains are very common.

Inadequacy of waste collection and disposal methods was identified as the main obstacle in waste management in the study area. According to the residents, the responsibility of controlling water pollution lies mainly with KMC. However, there are many other stakeholders including government sector organizations who directly or indirectly involve in water resources management in the catchment area. These stakeholders have different responsibilities towards water resources management in the area. The analysis revealed that the relationship among different stakeholders is highly diverse and as a result, their contribution to control water pollution in Meda Ela is also very different. Hence, community and other stakeholders should get together in order to develop an efficient and effective management plan to safeguard the Meda Ela stream and its catchment area,

\section{ACKNOWLEDGEMENTS}

The authors wish to acknowledge the Crossing Boundaries (CB) Project of the Postgraduate Institute of Agriculture, University of Peradeniya, for providing financial support to carry out the study.

\section{REFERENCES}

Abeysinghe, A.M.C.P.K. (2007). Willingness to pay for wastewater disposal by commercial water users in Kandy municipality, Unpublished Final Year Project Report, ECON/07/02, University of Peradeniya, Sri Lanka.

Jayakody, P., Raschid-Sally, L., Abeywardana, S.A.K. and Najim, M. (2006). Sustainable development of water resources, water supply and environment sanitation, $32^{\text {nd }}$ WEDC International Conference, Colombo, Sri Lanka. 
Storey, D. (2005). Urban Water pollution, communities and the state in South Asia, Massey University Paper presented to the workshop on Water in Mainland Southeast Asia, Siem Reap, 30 November to 2 December.

Water Supply Augmentation Project (2002). The Detailed Design study on Greater Kandy Water Supply Augmentation Project, Final Report, Volume II-I, Main Report (I), Japan International Co-operation Agency (JICA).

Urban Development Authority, (2001). Situation Report, Development Plan for Urban Development Area of Kandy, Sri Lanka.

Urban Development \& Water Supply Ministry, (2005). Millennium Development Goals: Kandy Municipal Council, Situation Report, Merg publication.

Wijekoon, W.B.M.M.W. and Herath, G. (2006). Pollution assessment in tributary waters of Mahaweli River around Kandy city, Forestry and Environment Symposium 2001, University of Sri Jayawardenapura, Sri Lanka. 